DOI 10.31558/2519-2949.2019.3.5

УДК 323.2-053.81(4+477)

ORCID ID: https://orcid.org/0000-0001-5936-5889

Краснопольська Т. М., Національний університет «Одеська юридична акдемія»

\title{
ЄВРОПЕЙСЬКІ МОДЕЛІ МОЛОДІЖНОЇ ПОЛІТИКИ ТА ПЕРСПЕКТИВИ ДЛЯ УКРАЇНИ
}

\begin{abstract}
В статті розглянуто поняття «молодіжна політика» та «державна молодіжна політика», проаналізовано основні моделі молодіжної політики, вироблені світовою практикою, а саме: консервативна (державна підтримка надається лише тим особам, що знаходяться в найбільш складній матеріальній ситуаиії, при цьому держава жорстко контролює витрачання виділених коштів та сама визначає їі адресатів), модель сочіального партнерства (в їі основі лежить принцип визнання особливої ролі держави та чіткої регламентачії законом заходів підтримки молодих людей і молодіжних організацій), соиіально-державна (держава бере на себе більшість функцій та охоплює регулюванням всю молодь в иілому, проте майже не враховує інтереси громадянського суспільства та бізнесу у сфері молодіжної політики), комунітарна (патерналістська державна молодіжна політика, характерна для авторитарного політичного режиму, держава повністю бере на себе функиії з регулювання роботи з молоддю).

Крім того розглянуто європейські моделі такої політики, виділені в залежності від режиму впровадження молодіжної політики (універсалістська, протекиіоністська, модель на базі громад та централізована). В основі периої лежать принципи самостійності та незалежності молоді, а також активної співпраці громадянського суспільства з державою в реалізації молодіжної політики. Друга характеризується вираженою соиіальною спрямованістю та націлена на допомогу молоді. Модель на базі громад передбачає мінімальну участь держави та широкі повноваження для громадянського суспільства. Для останньої характерно те, щцо провідна роль в реалізації прав молоді належить не державі, а сім'ї та иеркві.

Встановлено, що оптимальною для побудови в Україні є сформована скандинавськими краӥнами модель сочіального партнерства або універсалістська, за якої суб' єктами молодіжної політики є не лише інститути держави, а й громадянського суспільства. За такої моделі можливе найбільш широке використання потениіалу молоді для розвитку суспільства і держави.
\end{abstract}

Ключові слова: молодіжна політика, державна молодіжна політика, моделі молодіжної політики, СС.

Євроінтеграційний курс України та демократизація суспільно життя вимагають від нашої держави активних кроків щодо впровадження прогресивного зарубіжного досвіду реформ основних сфер суспільного життя. Такі трансформації можливі лише за умови використання системного підходу. Стратегічною метою нашої держави на шляху до євроінтеграції, на наш погляд, $\epsilon$ формування паритетної моделі демократії, за якої враховуються та забезпечуються інтереси всіх соціальних верств населення, групові інтереси найрізноманітніших соціальних груп (жінок i чоловіків, людей похилого віку и молоді, українців та іноземних громадян тощо). Одним з важливих напрямків внутрішньої політики на шляху до паритетної демократії має стати ефективна молодіжна політика. Оскільки саме молодь формуватиме політичний курс нашої держави в майбутньому, саме ій належить функція відтворення (як в біологічному, так і в соціальному сенсі).

Слід зазначити, що молодіжна політика привертає увагу не тільки практиків, а й багатьох теоретиків. Так, проблемам реалізації молодіжної політики присвятили свої праці і зарубіжні вчені: С. Вінард， Д. Галлі， І. Ільїнський， М. Карват， П. Лаурітцен， Ф. Мюллер， Е. Фром， М. Харрісон, К. Хартман-Фріч, А. Цокаліс тощо. До аналізу соціальних, політико-правових, державноуправлінських аспектів молодіжної політики в своїх працях звертались такі вітчизняні науковці, як I. Артеменко, В. Бебік, С. Бородін, М. Головатий, А. Данилов, М. Канавець, Г. Коваль, Н. Кожушко, В. Мотречко, Н. Метьолкіна, В. Панасюк, В. Ребкало, О. Яременко та інші.

Незважаючи на наукове опрацювання широкого кола питань щодо молодіжної політики, на даний час нашій державі необхідно чітко визначити модель такої політики та здійснювати

(C) Краснопольська Т. М., 2019 
системні заходи до іiі впровадження. Отже, метою даної статті є аналіз існуючих моделей та перспектив впровадження оптимальної для України.

Соціальні особливості молоді визначаються специфічною позицією, яку вона займає в процесі відтворення соціальної структури, а також здатністю не тільки наслідувати, а й перетворювати сформовані суспільні відносини. Протиріччя, що виникають всередині цього процесу, лежать в основі цілого комплексу специфічних молодіжних проблем. 3 одного боку, молодь $є$ найбільш мобільною частиною суспільства, серед цієї соціальної групи найбільш швидкими темпами відбувається підйом професійного рівня і службової кар'єри. 3 іншого боку, труднощі перехідного періоду суттєво відображаються на положенні молоді: складнощі адаптації до сучасних суспільнополітичних умов призводять до зниження соціального статусу, звужуються можливості доступу до освіти і культурних цінностей, одночасно розширюючи злочинність і девіантну поведінку, безробіття і соціальну нерівність.

Слід зазначити, що світове співтовариство, почало проводити цілеспрямовану політику по відношенню до молодого покоління починаючи з 1950-60-х років. Особлива роль належить Організації Об'єднаних Націй. У 1965 році ії Генеральною Асамблеєю була прийнята «Декларація про розповсюдження серед молоді ідеалів миру, взаємної поваги i взаєморозуміння між народами» [6]; в 1985 р, оголошеному Міжнародним роком молоді, були схвалені «Керівні принципи для подальшого планування і здійснення відповідних подальших заходів, що стосуються молоді: участь, розвиток, мир»; згідно з резолюцією Генеральної Асамблеї ООН від 14 грудня 1995 була прийнята Всесвітня програма дій, що стосуються молоді до 2000 року і на наступний період; резолюцією 54/120 від 20 січня 2000 року була схвалена Лісабонська декларація 3 молодіжної політики і програм [8].

Особливої уваги за заходів щодо захисту молодь потребує під час збройних конфліктів, що актуально для нашої держави в сучасних умовах. У 2015 році Радою Безпеки на її 7573-му засіданні 9 грудня 2015 року була прийнята Резолюція 2250 (2015), яка визначила стратегічні завдання молодіжної політики по відношенню до молодих осіб під час військових конфліктів: участь (у суспільно-політичному житті), захист, попередження (насильства i сприяння зміцненню соціальної згуртованості), партнерство, повернення і реінтеграція в суспільство [12].

Аналізуючи досвід нашої держави в цілому за період незалежності, можна дійти до висновку, що молодіжна політика $\epsilon$ недостатньо ефективною в нашій державі. Це обумовлено багатьма факторами. Так, низький рівень оновлення політичної еліти призводив до збереження негативних рис пострадянського типу мислення, бюрократизації та певного «старіння» еліти.

Проте події останніх років (військовий конфлікт на Сході нашої держави, криза легітимності влади тощо), а також перезавантаження правлячої еліти, яке відбулось в результаті президентських та парламентських виборів 2019 року, відкривають перспективи для позитивних змін в механізмі впровадження та реалізації молодіжної політики. Оскільки правляча еліти значно омолоджена. Наразі в нашій державі наймолодший прем'єр-міністр за весь період незалежності- Олексій Гончарук (якому 35 років). Крім того, середній вік його Кабміну 40 років, і це теж рекорд. Наймолодшому з команди, віце-прем'єру і міністру цифровий трансформації Михайлу Федорову 28 років [10]. Така ситуація сприяє тому, що влада не тільки розуміє інтереси молоді, вона належить до цієї соціальної групи. Тому недивно, що одним з перших завдань на наступний рік прем'єрміністр бачить дешеву іпотеку. Якщо така мета буде реалізована, показники одного з напрямів молодіжної політики (соціального захисту) суттєво підвищаться.

Молодіжна політика охоплює усі сфери життєдіяльності молоді, а також включає в себе виховання молоді, охоплює процеси соціалізації молоді, реалізації ії потенціалу та всю сукупність ідей щодо місця і ролі молоді в суспільстві.

Перед тим як переходити до моделей молодіжної політики, необхідно визначити ії поняття.

I. Ільїнський дає таке визначення молодіжної політики: «система ідей, теоретичних положень про місце і роль молодого покоління в суспільстві; практична діяльність суб'єктів такої політики щодо реалізації цих ідей, положень і директив з метою формування і розвитку молоді; реалізації творчих потенцій в інтересах будівництва нового суспільства» [7]. М. Головатий розглядає молодіжну політику як систему ідей, теоретичних положень про місце і роль молоді, молодого покоління в суспільстві; як практичну діяльність суб'єктів такої політики; як частину політики держави по соціалізації молодих громадян і відтворенню трудових ресурсів [2, с. 365].

А. Данилов визначає молодіжну політику як напрямок діяльності держави, мета якоїстворення необхідних соціально-економічних, організаційних умов і гарантій для соціального 
становлення і розвитку молоді, реалізація творчого потенціалу молодого покоління в інтересах розвитку суспільства $[5$, с. 209$]$.

3 наведених визначень видно, що автори часто не розмежовують такі поняття як «молодіжна політика» та «державна молодіжна політика». На наш погляд, перша включає другу. Оскільки суб'єктами молодіжної політики крім інститутів держави можуть бути партії, громадські, релігійні організацій, сама молодь тощо.

На думку М. Перепелиці, молодіжна політика є певною системою ідей, теоретичних положень стосовно місця, ролі та перспектив молоді в суспільстві, закріплених у законодавчих, нормативних актах, інших документах, а також діяльність суб'єктів молодіжної політики щодо втілення цих теоретичних положень у реальність. [11, с. 20]. Однією з ії складових є державна молодіжна політика.

За визначенням С. Рябухіна державна молодіжна політика являє собою діяльність органів влади щодо створення умов самореалізації молодої людини, соціально-позитивної діяльності молодіжних об'єднань і молодіжних ініціатив, діяльність по створенню визначених законодавством гарантій для молоді в правовій, економічній та інших сферах життя [13, с. 17.]. Даний підхід розглядає молодіжну політику як діяльність по створенню сприятливих, привілейованих умов для самореалізації та саморозвитку молоді.

Основним засобом розвитку потенціалу молоді $є$ iï залучення в соціально-економічне, суспільно-політичне та соціокультурне життя українського суспільства.

Державна молодіжна політика $є$ діяльністю держави, спрямованою на створення правових, економічних та організаційних умов і гарантій для самореалізації особистості молодої людини і розвитку молодіжних об'єднань, рухів та ініціатив. Державна молодіжна політика висловлює в відношенні до молодого покоління стратегічну лінію держави на забезпечення соціальноекономічного, політичного і культурного розвитку України, на формування у молодих громадян патріотизму і поваги до історії і культурі батьківщини, до інших народів, на дотримання прав людини.

Далі звернемось до зарубіжного досвіду впровадження молодіжної політики.

У розвинених європейських країнах (Німеччина, Бельгія, Нідерланди, Великобританія, Франція, Італія) реалізується ефективна державна молодіжна політика. Форми іiі проведення різні, проте загальною тенденцією є широке залучення громадських організацій, а також активну участь державних органів у вирішенні проблем різних категорій молоді.

Є. Грачов виділяє чотири моделі молодіжної політики, вироблені світовою практикою [4, с. 44-48]:

1) консервативна - державна підтримка надається не всім молодим особам, а лише тим, що знаходяться в найбільш складній матеріальній ситуації, при цьому держава жорстко контролює витрачання виділених коштів та сама визначає ії адресатів. Така модель притаманна для США, де вона грунтується на мінімальній участі державних структур у соціалізації молоді; соціальна підтримка молоді оголошується справою благодійних приватних організацій [3, с. 37];

2) модель соціального партнерства (між державою та суспільством)- притаманна для скандинавських країн та Німеччини. Молодіжна політика будується виходячи з визнання особливої ролі держави та чіткої регламентації законом заходів підтримки молодих людей і молодіжних організацій. А. Ховрін так характеризує означену модель: «в сфері молодіжної політики соціальне партнерство дозволяє раціонально використовувати активність молодих людей в наданні допомоги дітям та молоді, створювати умови для забезпечення успішної соціалізації молодого покоління, особистісної самореалізації його представників, розумно інтегрувати потенціали партнерів, сприяючи підвищенню ефективності їх діяльності» [15, с. 146]. На думку дослідників, німецька модель вважається однією 3 найефективніших в Європі, оскільки тут існують спеціально розроблені закони, які зобов'язують роботодавців приймати на роботу молодих людей при заповненні вакансій або реорганізації виробництва [14, с. 171];

3) соціально-державна - провідну роль у формуванні та реалізації молодіжної політики відіграє держава, яка бере на себе більшість функцій та охоплює регулюванням всю молодь в цілому. Державні інститути виступають посередником між державою та молоддю. Така модель має позитивні наслідки за умови достатнього фінансування та демократичних принципів організації державної влади, оскільки дещо погано враховує інтереси громадянського суспільства та бізнесу. Такий перекіс в бік держави дещо обмежує потенціал молодіжної політики. Реалізація молодіжної політики за такої моделі відбувається на всіх рівнях влади: державному, регіональному та місцевому. Молодіжні проекти при цьому фінансуються також з бюджетів всіх рівнів; 
4) комунітарна -являє собою найбільш патерналістський варіант державної молодіжної політики, при якому держава повністю бере на себе функції з регулювання роботи з молоддю. Вона притаманна для авторитарних політичних режимів (наприклад, радянська модель 3 державними молодіжними організаціями, які в обов'язковому порядку охоплювали всю молодь).

Відповідно до звіту італійського дослідного інституту IARD, європейські моделі молодіжної політики також можуть бути розділені на чотири категорії, залежно від режиму впровадження такої політики:

- універсалістська - охоплює всю молодь, притаманна для скандинавських країн, основні принципи: самостійність та незалежність. Обов'язок формування та реалізації такої політики покладається, як правило на спеціалізоване міністерство. Держава активно співпрацює 3 громадянським суспільством для реалізації молодіжної політики. Права та пільги в ній поширюються на всіх молодих людей, присутня ефективна державна підтримка [16, p. 14];

- протекціоністська модель - притаманна для Німеччини - має яскраво виражену соціальну спрямованість та націлена на допомогу молоді. Остання в даній концепції розуміється як найбільш вразлива соціальна група, яка вимагає підвищеної уваги з боку держави, отже мета молодіжної політики - інтеграція молоді в суспільство та профілактика девіацій;

- модель на базі громад- сформована в Великобританії- передбачає мінімальну участь держави; молодіжна політика спрямована на найбільш проблемні групи та соціально незахищені групи молоді з метою попередження соціальних проблем. За такої моделі держава більшу частину повноважень передає громадянському суспільству та бізнесу, опікуючись лише проблемними категоріями громадян;

- централізована - характерна для країн Середземномор'я та постсоціалістичних держав провідну роль в реалізації прав молоді за такої моделі відіграє не держава, а сім'я та церква [17].

Отже, як показує зарубіжний досвід для ефективної реалізації молодіжної політики необхідно залучати до її формування не тільки інститути держави, а й громадянське суспільство. Таким чином, необхідно виходити 3 широкого трактування такої політики.

Тут необхідно погодитись з І. Артеменко та В. Мотречко, що необхідність розмежування двох понять: «молодіжна політика» та «державна молодіжна політика» $[1$, с. 23-25; 9, с. 7]. Оскільки друге вузьке трактування поняття призводить до вибору недемократичної моделі, коли державна одноосібно розробляє та впроваджує таку політику, встановлюючи чіткі іiї рамки.

Досвід політико-правового регулювання державної молодіжної політики в нашій державі показує початковий державно-громадський іï характер. Отже спочатку даний напрям діяльності був виключною прерогативою держави. Було сформовано патерналістську модель молодіжної політики. Проте в подальшому в результаті юридичного закріплення в якості суб'єктів молодіжної політики не тільки державних органів і їх посадових осіб, а й молодіжних об'єднань, їх асоціацій, молодих громадян, забезпечення безпосередньої фінансової участі держави в реалізації програм i проектів дитячих та молодіжних об'єднань, поєднання державних, громадських інтересів і прав особистості у формуванні та реалізації такої політики відбувається перехід до партнерської моделі.

Перший підхід дозволяв забезпечити соціальний захист молодих людей, які його потребують, другий - створив умови для нормального соціального і особистісного розвитку, самореалізації молоді і забезпечив ії повноцінну участь в процесах суспільного відтворення. Тим самим держава не тільки конституювала свою відповідальність за стан молодого покоління в суспільстві, а й визнала молодих громадян партнерами, потенціал яких повинен активно використовуватися в системі заходів, адресованих молодим [1, с. 95].

Таким чином, на нашу думку, формування дієвої молодіжної політики в нашій державі можливо лише за умови використання моделі соціального партнерства або універсалістської (притаманної для скандинавських країн), коли суб'єктами такої політики виступають як інститути держави, так і інститути громадянського суспільства, з переважаючою роллю молодіжних громадських організацій. Оскільки ніхто не знає краще потреб та проблем молоді ніж вона сама. На думку, В. Мотречко, суспільна молодіжна політика відображає сформовані настрої, наявний чи відсутній зв'язок поколінь, здатність суспільства сприяти соціалізації молодої людини, що виражається в діяльності формальних та неформальних інститутів громадянського суспільства [9, с. 7]. Цей напрям політики тісно переплітається 3 державною молодіжною політикою та сприяє іiі реалізації та оптимізації. Таким чином, корисним для України є досвід скандинавських країн. 


\section{Бібліографічний список:}

1. Артеменко I. В. Взаємодія органів державної влади та інститутів громадянського суспільства у формуванні й реалізації молодіжної політики: дис... канд. наук з держ. управління: 25.00.01 / Дніпропетровський регіональний інститут державного управління Національної академії державного управління при Президентові України, 2017. - 252 с. URL:

http://www.dridu.dp.ua/nauka/sv_rada_D/dis/Artemenko_dissertation.pdf

2. Головатий М. Ф. Молодіжна державна політика. Політологічний енциклопедичний словник / упоряд. В. П. Горбатенко; за ред. Ю. С. Шемшученка, В. Д. Бабкіна, В. П. Горбатенка. 2-ге вид., доп. і перероб. Київ: Генеза, 2004. 736 с.

3. Государственная молодежная политика: российская и мировая практика реализации в обществе инновационного потенциала новых поколений: монография / под общ. ред. В. А. Лукова. М.: Изд-во Моск. гуманит. ун-та, 2013. 280 с.

4. Грачев Е. Н. Молодежная политика в Европейском Союзе: национальный и наднациональный уровни: дисс... к-та полит. наук: 23.00.04 / Московский государственный институт международных отношений, 2019. $240 \mathrm{c}$.

5. Данилов А. Н. Молодежная политика : социологическая энциклопедия. Минск: Белорус. энцикл., 2003. $384 \mathrm{c}$.

6. Декларація про розповсюдження серед молоді ідеалів миру, взаємної поваги та взаєморозуміння між народами: Резолюція 2037 (XX) Генеральної Асамблеї від 07.12.1965 р. Офіиійний сайт Верховної Ради України. URL: https://zakon.rada.gov.ua/laws/show/995_289

7. Ильинский И. М. Молодежь и молодежная политика. Философия. История. Теория. М.: Голос, 2001. $696 \mathrm{c}$.

8. Лиссабонская декларация по молодежной политике и Брагский план действий в интересах молодежи (A/53/378). Библиотека документов ООН, связанных с молодежью. URL: http://www.un.org/youth.html.

9. Мотречко В. В. Організація діяльності суб’єктів місцевого самоврядування щодо реалізації молодіжної політики: автореф... дис... канд. наук з держ. управління: 25.00.04 / Одеський регіональний інститут державного управління Національної академії державного управління при Президентові України, 2018. 23 с. URL: http://www.oridu.odessa.ua/8/4/doc/aref_motr.pdf

10. Новый Кабмин - что известно о самом молодом правительстве в истории Украины. ГОРДОН. URL: https://gordonua.com/publications/novyj-kabmin-chto-izvestno-o-samom-molodom-pravitelstve-v-istoriiukrainy-1234037.html

11. Перепелиця М. П. Державна молодіжна політика в Україні: (регіональний аспект): монографія. Київ: Укр. ін-т соц. дослідж., Укр. центр політолог. менеджменту, 2001. 242 с.

12. Резолюція 2250 (2015), прийнята Радою Безпеки на їі 7573-му засіданні 9 грудня 2015 року. Представництво ООН в Україні. URL: http://www.un.org.ua/ua/informatsiinyi-tsentr/2250/4161-rezoliutsiia-22502015-pryiniata-radoiu-bezpeky-na-ii-7573-mu-zasidanni-9-hrudnia-2015-roku

13. Рябухин С. Н. Государственная молодежная политика: опыт, прогнозы, приоритеты. Аналитический вестник Совета Федерации ФС РФ. 2000. № 4(116). С. 5-21.

14. Сафонова А. С. Молодежная политика и молодежь в политике: зарубежный ОПЫТ. Исторические, философские, политические и юридические науки, культурология и искусствоведение. Вопросы теории и практики. Тамбов: Грамота, 2013. № 2 (28): в 2-х ч. Ч. II. С. 166-174. URL:

http://www.gramota.net/materials/3/2013/2-2/40.html

15. Ховрин А. Ю. Социальное партнерство в сфере реализации молодежной политики: дисс... д-ра социол. наук: 22.00.08 / Российский государственный технологический университет имени К.Э. Циолковского. M. $2010.357 \mathrm{c}$.

16. Kuznetsova D. Europeanization of Youth Policy: Case Study of Finland and Norway. University of Tampere. 64 p. URL: https://trepo.tuni.fi/bitstream/handle/10024/97782/GRADU-1437141641b.pdf?sequence=1\&isAllowed=y

17. Study on the state of young people and youth policy in Europe / IARD (ed.). Final Reports. Vol. 1: Executive Summary and Comparative Reports. 156 p. URL: http://www.politiquesenfancejeunesse.org/wpcontent/uploads/2016/04/Young-people-youth-policy-IARD-2001.pdf

\section{References:}

1. Artemenko I. V. Vzayemodiya organiv derzhavnoyi vlady` ta insty`tutiv gromadyans`kogo suspil`stva u formuvanni j realizaciyi molodizhnoyi polity`ky`: dy`s... kand. nauk z derzh. upravlinnya: 25.00.01 / Dnipropetrovs `ky`j regional’ny`j insty` tut derzhavnogo upravlinnya Nacional `noyi akademiyi derzhavnogo upravlinnya pry` Prezy`dentovi Ukrayiny”, 2017. - 252 s. URL: http://www.dridu.dp.ua/nauka/sv_rada_D/dis/Artemenko_dissertation.pdf

2. Holovatyy M. F. Molodizhna derzhavna polityka. Politolohichnyy entsyklopedychnyy slovnyk / uporyad. V. P. Horbatenko; za red. Yu. S. Shemshuchenka, V. D. Babkina, V. P. Horbatenka. 2-he vyd., dop. i pererob. Kyyiv: Heneza, 2004. 736 s.

3. Gosudarstvennaja molodezhnaja politika: rossijskaja i mirovaja praktika realizacii v obshhestve innovacionnogo potenciala novyh pokolenij: monografija / pod obshh. red. V. A. Lukova. M.: Izd-vo Mosk. gumanit. un-ta, 2013. $280 \mathrm{~s}$. 
4. Grachev E.N. Molodezhnaja politika v Evropejskom Sojuze: nacional'nyj i nadnacional'nyj urovni: diss... k-ta polit. nauk: 23.00.04 / Moskovskij gosudarstvennyj institut mezhdunarodnyh otnoshenij, 2019. $240 \mathrm{~s}$.

5. Danilov A. N. Molodezhnaja politika : sociologicheskaja jenciklopedija. Minsk: Belorus. jencikl., 2003.384 s.

6. Deklaraciya pro rozpovsyudzhennya sered molodi idealiv my`ru, vzayemnoyi povagy` ta vzayemorozuminnya mizh narodamy`: Rezolyuciya 2037 (XX) General`noyi Asambleyi vid 07.12.1965 r. Oficijny`j sajt Verxovnoyi Rady` Ukrayiny`. URL: https://zakon.rada.gov.ua/laws/show/995_289

7. Il'inskij I. M. Molodezh' i molodezhnaja politika. Filosofija. Istorija. Teorija. M.: Golos, 2001. $696 \mathrm{s.}$

8. Lissabonskaja deklaracija po molodezhnoj politike i Bragskij plan dejstvij v interesah molodezhi (A/53/378). Biblioteka dokumentov OON, svjazannyh s molodezh'ju. URL: http://www.un.org/youth.html.

9. Motrechko V.V. Organizaciya diyal nosti sub’yektiv miscevogo samovryaduvannya shhodo realizaciyi molodizhnoyi polity`ky`: avtoref... dy`s... kand. nauk z derzh. upravlinnya: 25.00.04 / Odes`ky`j regional`ny`j insty 'tut derzhavnogo upravlinnya Nacional noyi akademiyi derzhavnogo upravlinnya pry` Prezy`dentovi Ukrayiny’, 2018. 23 s.. URL: http://www.oridu.odessa.ua/8/4/doc/aref_motr.pdf

10. Novyj Kabmin - chto izvestno o samom molodom pravitel'stve v istorii Ukrainy. GORDON.

URL: https://gordonua.com/publications/novyj-kabmin-chto-izvestno-o-samom-molodom-pravitelstve-v-istoriiukrainy-1234037.html

11. Perepelytsya M. P. Derzhavna molodizhna polityka v Ukrayini: (rehional'nyy aspekt): monohrafiya. Kyyiv: Ukr. in-t sots. doslidzh., Ukr. tsentr politoloh. menedzhmentu, 2001. 242 s.

12. Rezolyuciya 2250 (2015), pry`jnyata Radoyu Bezpeky` na yiyi 7573-mu zasidanni 9 grudnya 2015 roku. Predstavny`cztvo OON v Ukrayini. URL: http://www.un.org.ua/ua/informatsiinyi-tsentr/2250/4161-rezoliutsiia-22502015-pryiniata-radoiu-bezpeky-na-ii-7573-mu-zasidanni-9-hrudnia-2015-roku

13. Rjabuhin S. N. Gosudarstvennaja molodezhnaja politika: opyt, prognozy, prioritety / S. N. Rjabuhin / Analiticheskij vestnik Soveta Federacii FS RF. 2000. № 4(116). S. 5-21.

14. Safonova A. S. Molodezhnaja politika i molodezh' v politike: zarubezhnyj OPYT. Istoricheskie, filosofskie, politicheskie i juridicheskie nauki, kul'turologija i iskusstvovedenie. Voprosy teorii i praktiki. Tambov: Gramota, 2013. № 2 (28): v 2-h ch. Ch. II. C. 166-174. URL: http://www.gramota.net/materials/3/2013/2-2/40.html

15. Hovrin A. Ju. Social'noe partnerstvo v sfere realizacii molodezhnoj politiki: diss... d-ra sociol. nauk: 22.00.08 / Rossijskij gosudarstvennyj tehnologicheskij universitet imeni K.Je. Ciolkovskogo. M. 2010. 357 s.

16. Kuznetsova D. Europeanization of Youth Policy: Case Study of Finland and Norway. University of Tampere. 64 p. URL: https://trepo.tuni.fi/bitstream/handle/10024/97782/GRADU-1437141641b.pdf?sequence=1\&isAllowed=y

17. Study on the state of young people and youth policy in Europe / IARD (ed.). Final Reports. Vol. 1: Executive Summary and Comparative Reports. 156 p. URL: http://www.politiquesenfancejeunesse.org/wp-content/uploads/ 2016/04/Young-people-youth-policy-IARD-2001.pdf

\section{Krasnopolska T. M. European models of youth policy and prospects for Ukraine}

The article discusses the concepts of "youth policy" and "state youth policy", analyzes the main models of youth policy produced by world practice, namely: conservative (state support is given only to those who are in the most difficult financial situation, while the state tightly controls spending of funds and defining its recipients), model of social partnership (based on the principle of recognition of the special role of the state and clear regulation by law of measures to support young people actions and youth organizations), sociostate (the state assumes most functions and covers the regulation of all young people as a whole, but almost does not take into account the interests of civil society and business in the field of youth policy),

communitarian (paternalistic state youth policy, characteristic of authoritarian politics regime, the state is fully responsible for regulating youth work). In addition, European models of such policy, which are distinguished depending on the regime of youth policy implementation (universalist, protectionist, community-based model and centralized), are considered. The first is based on the principles of youth autonomy and independence, as well as the active cooperation of civil society with the state in the implementation of youth policy. The second is characterized by a strong social orientation and is aimed at helping young people. The community-based model envisages minimal government involvement and broad powers for civil society. The last one is characterized by the fact that the leading role in the realization of youth rights belongs not to the state, but to the family and the church. It is established that the social partnership or universalist model, formed by the Scandinavian countries, is optimal for construction in Ukraine. In this model, the widest possible use of youth potential for the development of society and the state is possible.

Key words: youth policy, state youth policy, models of youth policy, EU. 